\title{
USING LACTOBACILLUS bacteria AS IN-OVO INJECTION OR ORAL ADMINISTRATION TO IMPROVE THE PERFORMANCE OF BROILER CHICKS
}

\author{
Amal M. Hassan ${ }^{\text {* }}$, I. El-Wardany ${ }^{2}$ and M.I. Shourrap ${ }^{2}$ \\ 1- Animal and Poultry Physiology Department, Desert Research Center, Cairo Egypt, * Email: \\ amalmhassan@yahoo.com), 2- Poultry Production Department, Faculty of Agriculture, Ain Shams \\ University, Cairo, Egypt.
}

Received: 29/1/2018

\section{SUMMARY}

One hundred and sixty broiler fertile eggs with an average weight of $68.61 \mathrm{~g}$ were used to determine the best way to deliver probiotic and prebiotic to the chicken embryos. The eggs were obtained from a commercial Hubbard parent flock at 48 weeks of age. At $17^{\text {th }}$ day of incubation, the eggs were divided into four main groups, each of 40 eggs. The first group served as control $(C)$, while the second and third were subjected to in ovo injection with Lactobacillus bacteria (LB) at concentration of $9.8 \times 10^{9} \mathrm{cfu}(0.1 \mathrm{ml} / \mathrm{egg})$ either into air cell (Br group) or the amniotic fluid (Bm group). The hatched chicks of the $4^{\text {th }}$ group were orally inoculated $(O)$ with the same dose of bacteria immediately after post hatching.

The obtained results can be summarized as follows:

- Administration of LB either orally or in - ovo injection had a positive effect on feed consumption and live body weight at $5^{\text {th }}$ week of age.

- The chicks of Bm group showed the highest relative weight of carcass components, while those of $O$ group showed the lowest abdominal fat. In addition, administration of LB resulted in significantly $(P<0.05)$ higher relative weight of liver.

- Plasma total protein, globulin and A/G ratio did not significantly $(P<0.05)$ influenced by treatments.

- Chicks of O group showed a significant $(P<0.05)$ decrease in albumin level.

- Total bacterial count and total lactic acid bacteria were increased significantly $(P<0.05)$ in the $O$ group compared to the $C$ group.

Histological examination of tissues showed an improvement in ilium villi height of treated groups than in the control group.

Keywords: In ovo injection, Lactobacillus, blood, ilium histomorphology, lymphoid organs and broiler chicks

\section{INTRODUCTION}

There are a few ways to prescripetion of probiotics, the most common way is adding it to feed or drinking water, while spraying and oral gavage are other ways. Conventionally, in-feed or in-water supplementation has been used at the first hours/days post hatching. However, this approach relies on the amount of feed and/or water intake, the quality of water and other experimental factors (Biggs et al., 2007). Moreover, during early post-hatching period, infection of chicks by detrimental bacteria is also possible.

In ovo approach for injection of probiotics directly to the incubating egg has been developed. It allows for a precise delivery of the bioactive substance to all embryos at early stage of development, which unifies the effects of probiotics across the flock and assures proper development of gut microflora in all chicks. In ovo methodology may be applied in order to supply the embryo with additional nutrients prior to hatching and those nutrients will continue to be utilized by the chick post-hatch during the fasting period (SLawinska et al., 2014).
Based on chemical and physical features and dose of the injected substance, different site of injection (i.e. the embryo, the amnion, the allantois, the air cell or the yolk sac) and embryo age $(0,12,17$ or 18 days of incubation) have been used (Pilarski et al., 2005). Uni, et al., (1995) indicated that day 12 of incubation is the optimal time for probiotic injection into the air cell of the incubating egg, where at this time, embryo is totally immersed in amniotic fluid and is completely developed and highly vascularized, allowing for transfer of the bioactive solution from air cell to embryonic gastrointestinal tract.

This method (in ovo technique) has been successfully used for prebiotics and probiotics (Bednarczyk et al., 2010) or synbiotics (Slawinska et al., 2014 and Pruszynska-Oszmalek et al., 2015). In ovo delivery of prebiotics was found to improve growth rate, feed intake, nutrient digestibility (Bednarczyk et al., 2010) and meat quality Moreover, significant increase was found in total activity of pancreatic enzymes (Pruszynska-Oszmalek et al., 2015) and immune system development and function (Slawinska et al., 2014 b).

Injection of probiotic bacteria intra egg may be an alternative to microbiota acquisition by chicks before 
hatching and may reduce or avoid the gastrointestinal colonization by pathogens. Three species of bacteria, Bacillus subtilis, Enterococcus faecium, and Pediococcus acidilactici, are naturally occurring microbiota in the intestine of birds and common in commercial probiotic products (Manes et al., 2017). Recently, Bacillus, Lactobacillus and Saccharomyces are the major strains applied in broilers. The mechanisms of action of in ovo injected bioactive substances are complex (Slawinska et al., 2014), but researchers still predict their positive effects on organism growth and body weight.

Therefore, the objective of the current study was to determine the effect of prebiotics administered in ovo at the $17^{\text {th }}$ day of incubation on growth performance, carcass traits, and histomorphological traits of the small intestine, intestinal microflora and some plasma biochemical parameters of broiler chicks at the $5^{\text {th }}$ week of age. The main aim was to find the best way to introduce Lactobacillus bacteria to broiler chicks.

\section{MATERIALS AND METHODS}

The present study was carried out at the poultry research unit belonging to Faculty of Agriculture, Ain Shams University, during the period from December (2015) to January (2016). Two hundred Hubbard fertile eggs with an average weight of $68.61 \pm 0.01 \mathrm{~g}$ were used in the present study. At day $14^{\text {th }}$ of the embryonic development, eggs were candled and the infertile eggs or early embryonic dead were culled. One hundred and sixty eggs were randomly divided into four treatment groups (40 eggs for each). The first group did not received any supplementation and served as control (C), while the $2^{\text {nd }}$ and $3^{\text {rd }}$ groups were subjected to in ovo injection with lactobacillus bacteria at a concentration of $9.8 \mathrm{x}$ $10^{9} \mathrm{cfu}(0.1 \mathrm{ml} / \mathrm{egg})$ into either air cell $(\mathrm{Br})$ or the amniotic fluid $(\mathrm{Bm})$, respectively. Egg injection procedure was carried out at day $17^{\text {th }}$ of the embryonic development. Hatched chicks of fourth group was orally inoculated $(\mathrm{O})$ with the same dose of bacteria immediately post hatching.

The fertile unhatched eggs were broken out, the percentages of late embryonic mortality, and hatchability percent were calculated based on the number of fertile eggs. At hatch, a total of 120 chicks representing the four treatment groups were randomly taken and transferred into four groups of 30 chicks, in three replicates (10 chicks each). All chicks were brooded in wire battery brooder. The chicks were fed ad libitum on commercial starter ration until 15 day of age $(23 \%$ crude protein, $3050 \mathrm{Kcal} / \mathrm{Kg}$ metabolizable energy,). From 16 to 35 day of age, the chicks were fed on grower ration $(21 \%$ crude protein, $3150 \mathrm{Kcal} / \mathrm{Kg}$ metabolizable energy). Chicks were vaccinated against the common viral diseases in the local area. No antibiotics were added to drinking water or feed during the whole experiment period, but multivitamins were added weekly to drinking water during the whole experimental periods.
Chicks were individually weighed at hatch and then at 2 and 5 weeks of age till the $5^{\text {th }}$ week of age, then average body weight gain (BWG) was calculated (g/bird/period). Feed consumption (FC) was determined as $\mathrm{g} / \mathrm{bird} /$ period. Feed conversion ratio (FCR) was calculated according to the following equation:

$$
\mathrm{FCR}=\mathrm{FC}(\mathrm{g}) / \mathrm{BWG}(\mathrm{g})
$$

A total of 24 blood samples (six samples per group) were collected at the $5^{\text {th }}$ week of age during their exsanguinations into heparinized Wassermann tubes. Plasma samples were harvested directly after bleeding and centrifugation of blood samples were done at $4000 \mathrm{rpm}$ for $10 \mathrm{~min}$ using laboratory Centrifuge (Hettich Zenttrifugen, Germany). The plasma samples were stoppered tightly and stored in a deep freezer at $-20^{\circ} \mathrm{C}$ until the biochemical analysis were done. Plasma total proteins $(\mathrm{g} / \mathrm{dl})$ were determined according to the method described by Henry (1974). Plasma albumin (g/dl) was measured as described by Doumas et al. (1971). Globulin (g/dl) was calculated by subtracting plasma albumin from total protein, then $\mathrm{A} / \mathrm{G}$ ratio was calculated.

The material for the morphological and histological analysis of the duodenum was collected at 35-day-old chickens of each. Before slaughter, a total of 20 chickens (a representative selection) from each group were weighed, and their mean body weight was calculated. Subsequently, 10 chickens per group, with the body weight similar to the mean for the group were selected. After slaughter, the small intestine was removed out and the duodenum was dissected, measured and weighed. Samples for histomorphometric analyses (approx. $2 \mathrm{~cm}$ ) were taken from the midway of the duodenum.

Data were subjected to a one-way analysis of variance using the General Linear Models procedure of SAS, (2004), according to the following model:

$$
Y_{i j}=\mu+T_{i}+\varepsilon_{i j}
$$

Where:

$Y_{i j}=$ the $j$ observation of the $i^{\text {th }}$ bacterial treatment;

$\mu \quad=$ an effect of the overall mean;

$T_{i} \quad=$ a fixed effect of $i^{\text {th }}$ bacterial treatment;

$\varepsilon_{i j}=$ a random experimental error assumed NID $\left(0, \sigma \mathrm{e}^{2}\right)$

The differences among means were determined using Duncan's new multiple range test (Duncan, 1955). Statistical significance was accepted at a probability level of $0.05(\mathrm{P} \leq 0.05)$.

\section{RESULTS AND DISCUSSION}

\section{Growth performance:}

The effect of prebiotics administered in ovo at the $17^{\text {th }}$ day of incubation on growth performance is illustrated in table (1). The live body weight (LBW) was not significantly affected by treatment except at 2 weeks of age, where the chicks of $(\mathrm{Br})$ group achieved the highest weight. At the end of 
experiment, the chicks of both in ovo and oral inoculation of $L A C T$ showed the highest LBW and

BWG.

Table 1. Effects of experimental treatments on live body weight and gain (g) of broiler chickens

\begin{tabular}{|c|c|c|c|c|}
\hline \multirow[t]{3}{*}{ Age } & \multicolumn{4}{|c|}{ Treatment } \\
\hline & $\mathbf{C}$ & $\mathbf{B r}$ & $\mathbf{B m}$ & $\mathbf{O}$ \\
\hline & \multicolumn{4}{|c|}{ Live body weight (g) } \\
\hline 1d & $49.93 \pm 0.621$ & $48.79 \pm 0.125$ & $48.81 \pm 0.245$ & $49.22 \pm 0.547$ \\
\hline 2 wks & $476.75^{\mathrm{b}} \pm 4.151$ & $548.67^{\mathrm{a}} \pm 43.956$ & $489.60^{\mathrm{b}} \pm 8.465$ & $527.00^{\mathrm{ab}} \pm 5.568$ \\
\hline \multirow[t]{2}{*}{5 wks } & $1985.50 \pm 70.638$ & $2075.67 \pm 62.691$ & $2066.40 \pm 26.628$ & $2075.33 \pm 7.881$ \\
\hline & \multicolumn{4}{|c|}{ Body weight gain $(g)$} \\
\hline 0-2 wks & $426.75^{\mathrm{bc}} \pm 4.662$ & $500.00^{\mathrm{a}} \pm 44.276$ & $440.60^{\mathrm{bc}} \pm 8.704$ & $478.00^{\mathrm{ab}} \pm 6.028$ \\
\hline 3-5 wks & $1509.00 \pm 67.513$ & $1526.33 \pm 28.038$ & $1577.00 \pm 23.843$ & $1548.33 \pm 4.177$ \\
\hline 0-5 wks & $1935.50 \pm 70.918$ & $2026.67 \pm 62.691$ & $2017.40 \pm 26.593$ & $2026.33 \pm 8.453$ \\
\hline
\end{tabular}

These results are in full agreement with that reported by Dankowiakowska et al. (2013); Cox (2013) and Slawinska et al. (2014), who found that in ovo inoculation of $L A C T$ bacteria strains resulted in improving the productive performance of broiler chicks. The improvement in both LBW and BWG by in ovo injection of LACT might be due to reduction of pathogenic bacteria number in the intestine by competitive exclusion, production of antimicrobial substances such as lactic and acetic acids that inhibit a wide range of gram-positive and gram-negative bacteria (Williams and Zedeka, 2010) and/or modulation of immune responses of chicks during post hatching growth. This means that treating chicks by $L A C T$ which improved feed utilization might be through improving some metabolic processes.

On the other hand, same investigators found no effect on post hatch growth performance of broileable through in ovo inoculation of LACT bacteria, (Edens et al., 1997 and Stern et al., 2001).

\section{Feed consumption and feed conversion ratio:}

The treatments did not affect feed consumption (Table 2). The $\mathrm{Br}$ group showed a significant improvement $(\mathrm{P}<0.01)$ in feed conversion ratio at the period $0-2$ weeks of age compared with control. At the end of the experiment (five weeks of age), all groups showed nearly the same feed conversion ratio. Cox (2013) and Oliveira de et al. (2014) found the same trend; in ovo, treatment with different doses of primalac (a probiotic compound) had no significant effect on feed consumption or feed conversion of broiler chicks. On the other hand, Bednarczyk et al. (2010) found improvement in nutrient digestibility and Pruszynska-Oszmalek et al. (2015) observed significant increase in total activity of pancreatic enzymes (amylase, lipase and trypsin).

Table 2. Effect of experimental treatments on feed consumption and feed conversion ratio of broiler chicks at 35 day of age

\begin{tabular}{lcccc}
\hline \multirow{2}{*}{$\begin{array}{c}\text { Age } \\
\text { wks }\end{array}$} & $\mathbf{C}$ & $\mathbf{B r}$ & $\mathbf{B m}$ & $\mathbf{O}$ \\
\cline { 2 - 4 } & \multicolumn{5}{c}{ Treatment } \\
$\mathbf{0 - 2}$ & $524.50 \pm 4.173$ & $526.67 \pm 41.273$ & $526.80 \pm 11.876$ & $558.33 \pm 11.465$ \\
$\mathbf{3 - 5}$ & $2399.75 \pm 73.673$ & $2464.00 \pm 77.078$ & $2497.60 \pm 46.427$ & $2494.33 \pm 78.252$ \\
$\mathbf{0 - 5}$ & $2924.00 \pm 74.720$ & $2990.33 \pm 107.667$ & $3024.00 \pm 56.384$ & $3053.00 \pm 76.167$ \\
\cline { 2 - 4 } & $1.23^{\mathrm{ab}} \pm 0.020$ & \multicolumn{5}{c}{ Feed conversion ratio } \\
$\mathbf{0 - 2}$ & $1.59 \pm 0.022$ & $1.06^{\mathrm{c}} \pm 0.062$ & $1.20^{\mathrm{b}} \pm 0.019$ & $1.17^{\mathrm{b}} \pm 0.016$ \\
$\mathbf{3 - 5}$ & $1.51 \pm 0.019$ & $1.61 \pm 0.037$ & $1.59 \pm 0.037$ & $1.61 \pm 0.054$ \\
$\mathbf{0 - 5}$ & $1.48 \pm 0.023$ & $1.50 \pm 0.027$ & $1.51 \pm 0.044$ \\
\hline a,b,c Means within the same row with no common superscript differ significantly. C, (negative control); O, (oral with \\
Lactobacillus bacteria); Br, (in ovo injection with Lactobacillus bacteria in air sac); Bm, (in ovo injection with \\
Lactobacillus bacteria in amniotic fluid). *P $\leq 0.05, * *$ P $\leq 0.01, \mathrm{NS}=$ non-significant.
\end{tabular}

\section{Carcass traits:}

Carcass traits as affected by treatments are shown in Table (3). At marketing age (5 weeks), the chicks of $\mathrm{Bm}$ group showed the highest $(\mathrm{P}<0.05)$ carcass relative weight with significantly different than $\mathrm{O}$ group only. Chicks of $\mathrm{Br}$ and $\mathrm{Bm}$ groups had the highest $(\mathrm{P}<0.05)$ abdominal fat, while those of $\mathrm{Bm}$ and $\mathrm{O}$ groups showed the highest $(\mathrm{P}<0.05)$ liver relative weight. Relative weight of heart, gizzard and gizzard fat were not significantly $(\mathrm{P}<0.05)$ affected by treatments. Chicks of the oral inoculated (O) group has the significant abdominal fat (\%) compared to $\mathrm{Br}$ and $\mathrm{Bm}$. Our results are in full agreement with that reported by El-Husseiny et al. 
(2001); Yosrizal and Chen (2003) and Tollba and Mahmoud (2009) who showed that Lactobacillus acidophilus bacteria in the broiler diets decreased abdominal fat percentage. Moreover, Willis et al. (2007) observed a decrease in carcass yield percentage as a result of oral inoculated of LB. However, Awad et al. (2009) reported that the carcass percentage was not affected by probioticsupplementation.

Table 3. Effect of experimental treatments on relative weight of carcass and relative org and weight of broiler chicks

\begin{tabular}{lcccc}
\hline \multirow{2}{*}{ Traits (\%) } & \multicolumn{4}{c}{ Treatment } \\
\cline { 2 - 5 } & $\mathbf{C}$ & $\mathbf{B r}$ & $\mathbf{B m}$ & $\mathbf{O}$ \\
\hline Carcass & $74.13^{\mathrm{ab}} \pm 0.541$ & $73.967^{\mathrm{ab}} \pm 1.536$ & $76.40^{\mathrm{a}} \pm 1.384$ & $72.65^{\mathrm{b}} \pm 0.211$ \\
Heart & $0.46 \pm 0.022$ & $0.50 \pm 0.023$ & $0.45 \pm 0.015$ & 0.440 .023 \\
Liver & $1.96^{\mathrm{b}} \pm 0.106$ & $2.54^{\mathrm{a}} \pm 0.161$ & $1.91^{\mathrm{b}} \pm 0.096$ & $2.48^{\mathrm{a}} \pm 0.139$ \\
Gizzard & $0.85 \pm 0.067$ & $1.10 \pm 0.110$ & $1.07 \pm 0.163$ & $1.02 \pm 0.061$ \\
Abdominal Fat & $1.11^{\mathrm{ab}} \pm 0.173$ & $1.22^{\mathrm{a}} \pm 0.158$ & $1.29^{\mathrm{a}} \pm 0.118$ & $0.72^{\mathrm{b}} \pm 0.090$ \\
Gizzard Fat & $0.46 \pm 0.011$ & $0.48 \pm 0.087$ & $0.49 \pm 0.055$ & $0.46 \pm 0.077$ \\
\hline
\end{tabular}

${ }_{\mathrm{a}, \mathrm{b}, \mathrm{c}}$ Means within the same row with no common superscript differ significantly.

C, (control); O, (oral with Lactobacillus bacteria); Br, (in ovo with Lactobacillus bacteria in air sac); BM, (in ovo with Lactobacillus bacteria in amniotic fluid). $\quad * \mathrm{P} \leq 0.05, \mathrm{NS}=$ non-significant.

Plasma total protein, albumin and globulin:

It is clear from our results in table (4) that total protein (TP) and $A / G$ ratio were not significantly $(\mathrm{P}<0.05)$ influenced by treatments. Chicks of $\mathrm{O}$ group showed the lowest $(\mathrm{P}<0.05)$ albumin level. These results are in agreement with Mountzouris et al. (2010) and Torshizi et al. (2010).

Table 4 Effect of experimental treatments on plasma protein fractions (g/dl) of broiler chicks

\begin{tabular}{lcccc}
\hline \multirow{2}{*}{ Items } & \multicolumn{4}{c}{ Treatment } \\
\cline { 2 - 5 } & $\mathbf{C}$ & $\mathbf{B r}$ & $\mathbf{B m}$ & $\mathbf{O}$ \\
\hline Total Protein & $4.44 \pm 0.131$ & $4.47 \pm 0.147$ & $4.17 \pm 0.79$ & $4.29 \pm 0.121$ \\
Alb (A) & $2.38^{\mathrm{ab}} \pm 0.082$ & $2.41^{\mathrm{a}} \pm 0.083$ & $2.28^{\mathrm{ab}} \pm 0.040$ & $2.21^{\mathrm{b}} \pm 0.021$ \\
Glo (G) & $2.07 \pm 0.057$ & $2.06 \pm 0.077$ & $1.89 \pm 0.052$ & $2.09 \pm 0.103$ \\
A/G Ratio & $1.15 \pm 0.032$ & $1.17 \pm 0.034$ & $1.21 \pm 0.031$ & $1.06 \pm 0.051$ \\
\hline
\end{tabular}

${ }^{\mathrm{a}, \mathrm{b}, \mathrm{c}}$ Means within the same row with no common superscript differ significantly.

C, (control); O, (oral with Lactobacillus bacteria); $\mathrm{Br}$, (in ovo with Lactobacillus bacteria in air sac); $\mathrm{Bm}$, (in ovo with Lactobacillus bacteria in amniotic fluid). $\quad * \mathrm{P} \leq 0.05, * * \mathrm{P} \leq 0.01, \mathrm{NS}=$ non-significant.

\section{The Ilium histology:}

The data on ilium histology is shown in table (5). The transverse section through ilium revealed that musculosa depth was not affected by treatment. Oral inoculation with Lactobacillus bacteria (O group) in significant $(\mathrm{P}<0.05)$ ilium villi height, villi diameter (Fig. 1) and the ratio of villus height to crypt depth (Table 5). Injection in-ovo of Lactobacillus into air sac $(\mathrm{Br}$ group) resulted in the highest $(\mathrm{P}<0.05)$ crypts depth (Table 5). Also, chicks of both groups $\mathrm{C}$ and $\mathrm{Br}$ showed a good development in crypts in the submucosa layer (Fig. 1). On the other hand, the chicks of $\mathrm{Bm}$ group showed the lowest villi height and crypts depth (Table 5).

Oral inoculation hatched chicks with Lactobacillus bacteria (O group) and in ovo- amnion injection (Bm group) caused an increase in villi diameter with many well developed crypts in the sub- mucosa layer as shone in Histological sections. The villi and the size of crypts appeared shorter and blunt for both groups compared with the control and in ovo administration of Lactobacillus into air sac group of chicks (Fig. 2- $\mathrm{C}$ and $\mathrm{Br}$ ). This holds true as the crypt depth of Br-treatment and oral-treatment groups was significantly higher than the other groups (Table 5). The crypts of Lieberkuhn secreted fluids containing different vital substances essential for enhancing the internal micro-environment of the intestine segments. These fluids are rapidly absorbed from the villi lumens elaboration and production of antibodies and lymphocytes along with an increase in goblet cells which secrets substances responsible for reducing $\mathrm{PH}$ of the intestinal segment, Hodes (1974); Roberfroid (2000) and Pelicano et al. (2005). 
Table 5. Effect of Lactobacillus acidophilus administration on ilium histomorphological parameters of broiler chicks at 35 day of age

\begin{tabular}{lcccc}
\hline \multirow{2}{*}{\multicolumn{1}{c}{ Items }} & \multicolumn{4}{c}{ Treatment } \\
\cline { 2 - 5 } & $\mathrm{C}$ & $\mathrm{Br}$ & $\mathrm{Bm}$ & $\mathrm{O}$ \\
\hline Musculosa depth $(\mu \mathrm{m})$ & $115.67 \pm 6.614$ & $120.60 \pm 2.540$ & $116.96 \pm 2.785$ & $114.63 \pm 7.010$ \\
Villus height $(\mu \mathrm{m})$ & $637.49^{\mathrm{b}} \pm 22.820$ & $610.08^{\mathrm{b}} \pm 24.238$ & $598.73^{\mathrm{b}} \pm 21.913$ & $755.86^{\mathrm{a}} \pm 20.452$ \\
Crypt depth $(\mu \mathrm{m})$ & $88.67^{\mathrm{b}^{\mathrm{c}}} \pm 2.422$ & $115.25^{\mathrm{a}} \pm 4.139$ & $76.21^{\mathrm{c}} \pm 3.688$ & $96.029^{\mathrm{b}} \pm 7.759$ \\
Villus height/crypt depth & $7.11^{\mathrm{b}} \pm 0.425$ & $5.49^{\mathrm{b}} \pm 0.311$ & $8.09^{\mathrm{ab}} \pm 0.474$ & $9.82^{\mathrm{a}} \pm 1.037$ \\
\hline
\end{tabular}

${ }_{\mathrm{a}, \mathrm{b}, \mathrm{c}}$ Means within the same row with no common superscript differ significantly. C, (control); O, (oral with Lactobacillus bacteria); Br, (in ovo with Lactobacillus bacteria in air sac); Bm, (in ovo with Lactobacillus bacteria in amniotic fluid); $* \mathrm{P} \leq 0.05, \mathrm{NS}=$ non-significant.
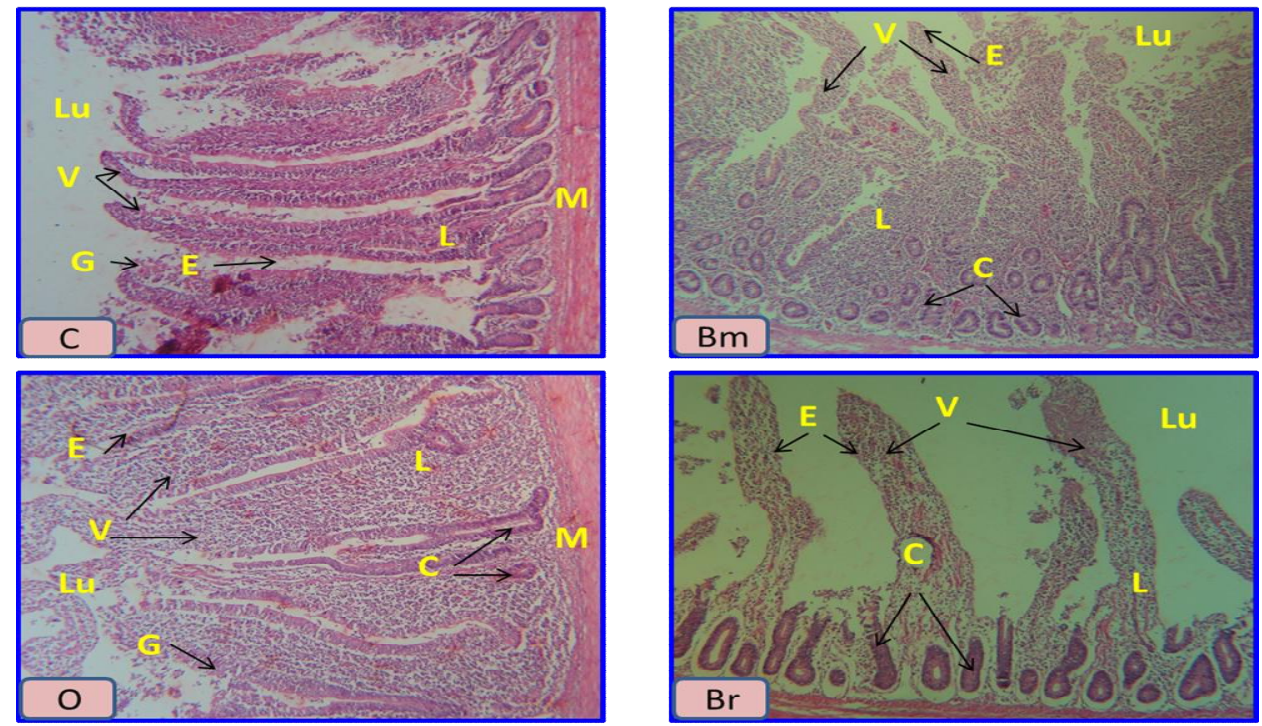

Figure 1. Transverse section through ilium from birds of different treatments at 35 day of age: C, (control); $\mathrm{O}$, (oral with Lactobacillus bacteria); Br, (in ovo with Lactobacillus bacteria in air sac); Bm, (in ovo with Lactobacillus bacteria in amniotic fluid). (Lu) lumen; (E) epithelial lining; (G) Goblet cells; (V) Villi; (C) Crypts of Lieberkuhn; (M) Muscular is mucosa;(L)Lamina propria. (H \& E $\times 10$ ).
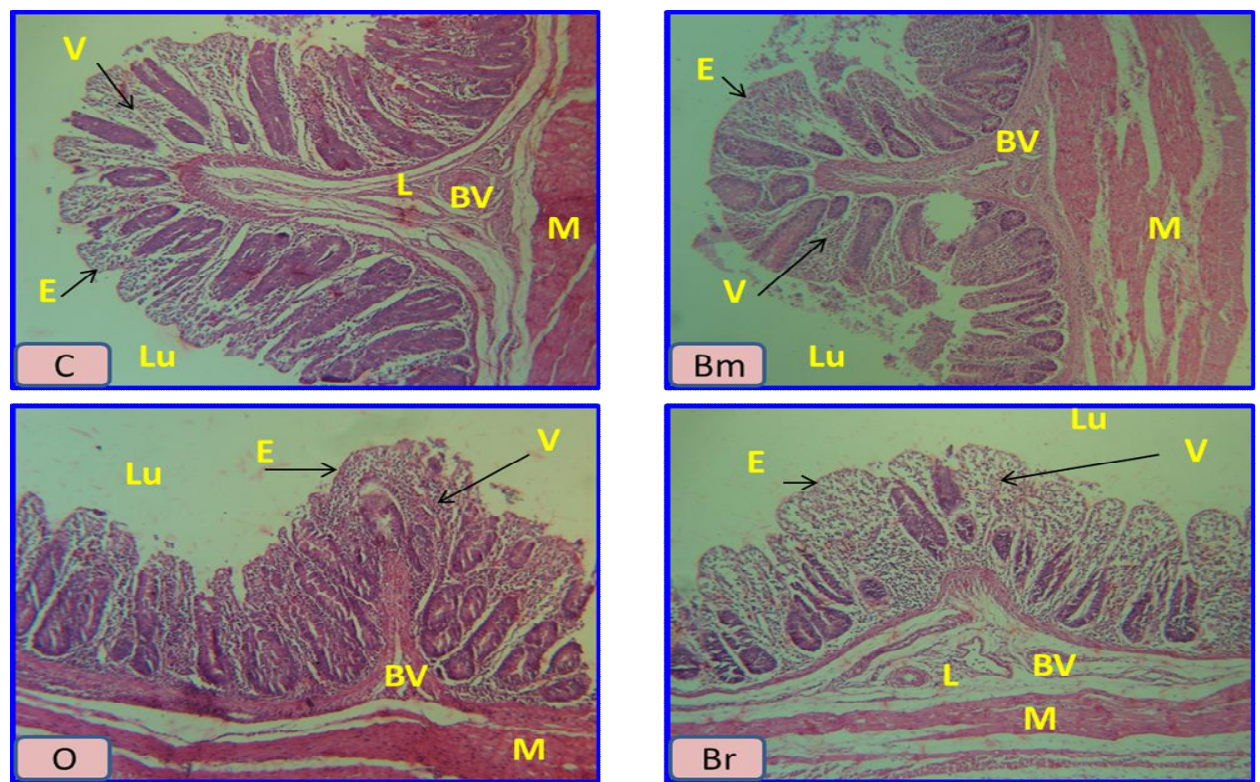

Figure 2. Transverse section through cecum from birds of different treatments at 35 day of age. C, (control); $\mathrm{O}$, (oral with Lactobacillus bacteria); Br, (in ovo with Lactobacillus bacteria in air sac); Bm, (in ovo with Lactobacillus bacteria in amniotic fluid).(Lu) lumen; (E) epithelial lining; (Bv) Blood vessels; (V) Villi; (M) Muscularis mucosa; (L) Lamina propria; (H \& E × 10). 


\section{The mucosa layers:}

The caecum sections were taken from the middle cecum and composed of similar layers as the other small intestine segments, with only slight variation due mainly to the part where the caecal specimen was dissected (proximal, middle, or distal caecum). Since the muscular is mucosa layer $(\mathrm{m})$ and is well developed with an outer longitudinal and inner circular layers being thick in the $\mathrm{BM}$ and $\mathrm{Br}$ sections than $\mathrm{C}$ and $\mathrm{O}$ ones. There are many lymph nodules containing numerous aggregates of lymphocytes with different size. The crypts of Lieberkuhn are short tubular ducts and laying in the base of the villi, where they occupy most of the tunica propria layer between the bases of the villi and the muscular is mucosa layers. The villi being well developed both in length and breadth but they are very short and blunt with a very well epithelial lining containing many goblet cells. These results are in accordance with the findings by Edens et al. (1997); Chichlowisk, et al. (2007), de Oliveira, et al. (2014) and Yamawaki, et al. (2013). They used in ovo injection of different probiotics and found similar and promising results.

Table 6. Effect of Lactobacillus acidophilus administration on cecum histomorphological parameters of broiler chicks at 35 day of age

\begin{tabular}{lcccc}
\hline \multirow{2}{*}{ Items } & \multicolumn{4}{c}{ Treatment } \\
\cline { 2 - 5 } & $\mathbf{C}$ & $\mathbf{B r}$ & $\mathbf{B m}$ & $\mathbf{O}$ \\
\hline Musculosa depth $(\mu \mathrm{m})$ & $119.00^{\mathrm{b}} \pm 6.00$ & $179.29^{\mathrm{a}} \pm 4.911$ & $143.50^{\mathrm{ab}} \pm 9.633$ & $150.83^{\mathrm{ab}} \pm 8.619$ \\
\hline Mucosa height $(\mu \mathrm{m})$ & $173.2^{\mathrm{c}} \pm 11.972$ & $190.76^{\mathrm{b}} \pm 3.199$ & $156.80^{\mathrm{c}} \pm 5.374$ & $211.45^{\mathrm{a}} \pm 4.517$ \\
\hline a,b,c Means within the same row with no common superscript differ significantly; C, (control); O, (oral with Lactobacillus \\
bacteria); Br, (in ovo with Lactobacillus bacteria in air sac); Bm, (in ovo with Lactobacillus bacteria in amniotic fluid); ${ }^{*} \mathrm{P} \leq$ \\
0.05, NS= non-significant
\end{tabular}

\section{CONCLUSION}

This study demonstrates that in ovo injection of probiotic into the air chamber of egg significantly influences the histomorphological parameters on 17 of rearing without negatively affecting productivity in chickens at the end of rearing.

\section{REFERENCES}

Alimohamadi, K., K. Taherpour, H. A. Ghasemi and F. Fatahnia, 2013. Comparative effects of using black seed (Nigella sativa) cumin seed (Cuminum cyminum), probiotic or prebiotic on growth performance, blood haematology and serum biochemistry of broiler chicks. J. Anim. Physiol. and Anim. Nutr., 98: 538-546.

Alkhalf, A., M. Alhaj and I. Al-homidan, 2010. Influence of probiotic supplementation on blood parameters and growth performance in broiler chickens. Saudi J. Biol. Sci., 17: 219-225.

Awad, W.A.; K. Ghareeb; S. Abdel-Raheem and J. Bohm, 2009. Effects of dietary inclusion of probiotic and symbiotic on growth performance, organs weight and intestinal histomorphology of broiler chickens. Pout. Sci., 88: 49 -59.

Bednarczyk, M.; J. Brzeziñska; A. SLawiñska; M. Siwek; M. Urbanowski and K. Kasperczyk, 2010. In ovo technology - a tool in modern poultry prophylaxis. Biotechnologia 88: 109-118.

Bednarczyk, M.; J. Brzeziñska; A. SLawiñska; M. Siwek; M. Urbanowski and K. Kasperczyk, 2010. In ovo technology - a tool in modern poultry prophylaxis. Biotechnologia 88: 109-118.

Bednarczyk, M.; J. Brzeziñska; A. SLawiñska; M. Siwek; M. Urbanowski and K. Kasperczyk, 2010. In ovo technology - a tool in modern poultry prophylaxis. Biotechnologia 88: 109-118.
Biggs, P.; C. M. Parsons and G. C. Fahey, 2007. The effects of several oligosaccharides on growth performance, nutrient digestibilities, and cecal microbial populations in young chcks. Poult. Sci., 86: 2327-2336.

Chichlowisk, MJ. BW. Croom; L. McBride; G. Daniel; R. Davis and MD. Koci, 2007. Direct-fed microbial primaLac and salinomycin modulate whole-body and intestinal oxygen consumption and intestinal mucosal cytokine production in the broiler chick. Poult. Sci., 86: 1100 - 1106.

Cox, C. M, 2013. In ovo supplementation of primalac and the effects on performance and immune response of broilers. Ph.D. Thesis, Animal and Poultry Science, Faculty of the Virginia Polytechnic Institute and State University, USA.

Dankowiakowska, A.; I. Kozłowska and M. Bednarczyk, 2013. Probiotics, prebiotics and snybiotics in poultry - mode of action, limitation, and achievements. Journal of Central European Agriculture, 14(1), p. 467-478.

Doumas, B. T.; W.A. Warson and N.G. Biggs, 1971. Albumin standards and the measurement of serum albumin with bromcresol green. Clin. Chem. Acta., 31: 87-96.

Duncan, D. B, 1955. Multiple range and multiple "F" test. Biometrics, 11: 1-42.

Edens, F. W.; C. R. Parkhurst; I. A. Casas and W. J. Dobrogosz,1997. Principles of Ex Ovo Competitive Exclusion and In Ovo Administration of Lactobacillus reuteri. Poult. Sci., 76:179-196.

El-Husseiny, O. M.; A. S. Abd El-Hakim and M. O. Abd El-Samee, 2001. Evaluation of probiotics in broiler diet based on plant protein. Egypt. J. Nutr. Feeds, 4: $957-965$.

Hashemzadeh, F.; S. Rahimi; M. A. Karimi Torshizi and A. A. Masoudi, 2013. Effects of probiotics 
and antibiotic supplementation on serum biochemistry and intestinal microflora in broiler chicks. Int. J. Agri. Crop Sci., 5(20): 2394-2398.

Hashemzadeh, Z.; M. K. Torshizi; Sh. Rahimi; V. Razban and T. Z. Salehi, 2010. Prevention of Salmonella colonization in neonatal broiler chicks by using different routes of probiotic administration in hatchery evaluated by culture and PCR techniques. J. Age. Sci. Tech., 12: 425 432

Henry, R. J, 1974. Clinical Chemistry: Principles and Techniques. New York, NY: Harper and Row.

Higgins, S. E.; J. P. Higgins; A. D. Wolfenden; S. N. Henderson; A. Torres-Rodringuez; G. Tellez and B. M. Hargis 2008. Evaluation of a Lactobacillusbased probiotic culture for the reduction of Salmonella enteritidis in neonatal broiler chicks. Poult. Sci., 87: 27-31.

Hodges, R. D, 1974. The histology of the fowl. 2 nd Ed. Academic press, London.

Karimi-Kivi, R.; M. Dadashbeiki and A. Seidavi, 2015. Growth, body characteristics and blood parameters of ostrich chickens receiving commercial probiotics. Span. J. Agri. Res., 13(1), e06-004, 11 pages.

Manes- lazaro, P.M.van dimen, C.P. Pin, M.J. Mayer, M.P. Stevens and Norbad, 2017. Administration of Lactobacillus johnsoniiFI9785 to chickens affects colonisation by Campylobacter jejuni and the intestinal microbiota. British Poultry Scince, 58, 2017

Mountzouris, K. C.; P. Tsistsikos; I. Palamidi; A. Arvaniti; M. Mohnl; G. Schatzmayr and K. Fegeros, 2010. Effects of probiotic inclusion levels in broiler nutrition on growth performance, nutrient digestibility, plasma immunoglobulins, and cecal microflora composition. Poult. Sci., 89(1): 58-67.

Oliveira de, J. E.; E. van der Hoeven-Hangoor; I. B. van de Linde; R. C. Montijn and J. M. B. M. van der Vossen, 2014. In ovo inoculation of chicken embryos with probiotic bacteria and its effect on posthatch Salmonella susceptibility. Poult. Sci., 93: 818-829.

Patterson, J. A. and K. M. Burkholder, 2003. Application of Prebiotics and Probiotics in Poultry Production1. Poult. Sci., 82:627-631.

Pelicano, E.R.; P. A. Souza; H. B. Souza; D. F. Figueiredo; M. M. Boiago; S. R. Carvalho and V. F. bordon, 2005. Intestinal mucosa development in broiler chickens fed natural growth promoters. Res. Brasil. Cienc. Avic., 4: 221- 229.

Pelicano, E.R.; P. A. Souza; H. B. Souza; D. F. Figueiredo; M. M. Boiago; S. R. Carvalho and V. F. bordon, 2005. Intestinal mucosa development in broiler chickens fed natural growth promoters. Res. Brasil. Cienc. Avic., 4: 221- 229.

Pruszynska-Oszmalek, E.; P.A. Kolodziejski; K. Stadnicka; M. Sassek; D. Chalupka; B. Kuston; L. Nogowski; P. Mackowiak; G. Maiorano; J.
Jankowski and M. Bednarczyk, 2015. In ovo injection of prebiotics and synbiotics affects the digestive potency of the pancreas in growing chickens. Poult. Sci., 00:1-8.

Roberfroid, M. B, 2000. Prebiotics and probiotics: are they functional foods. Am. J. Clin. Nutr. 71:1682-1687.

SAS 2004. SAS/STAT®User's Guide: Statistics Ver. $6.04,4^{\text {th }}$ ed. SAS Institute Inc., Cary, NC., U.S.A.

Scanlan, C. M, 1997. Current concepts of competitive exclusion cultures for the control of salmonellae in domestic poultry. Advances in experimental medical biology, 421: 421-426

Sharma, J. M, 2003. The avian immune system. Pages 5-16 in Diseases of Poultry Y. M. Saif ed. Iowa State Press, Ames, Iowa.

SLawinska; Siwekm; Yliñskaj; Bardowskj; Brzeziñskaj; A. Gulewiczk; Nowakm; Urbanowskim; P£owieca and Bednarczykm,2014. Influence of synbiotics delivered in ovo on immune organs development and structure. Folia Biologica (Kraków) 62:277-285.

SLawinska;; Siwekm; Yliñskaj; Bardowskj; Brzeziñskaj; A. Gulewiczk; Nowakm; Urbanowskim; P£owieca and Bednarczykm, 2014. Influence of synbiotics delivered in ovo on immune organs development and structure. Folia Biologica (Kraków) 62:277-285.

SLawinska; Siwekm; Yliñskaj; Bardowskj; Brzeziñskaj; A. Gulewiczk; Nowakm; Urbanowskim; P£owieca and Bednarczykm, 2014. Influence of synbiotics delivered in ovo on immune organs development and structure. Folia Biologica (Kraków) 62:277-285.

Stern, N. J.; N. A. Cox; J. S. Bailey; M. E. Berrang and M. T. Musgrove, 2001. Comparison of mucosal competitive exclusion and competitive exclusion treatment to reduce Salmonella and Campylobacter spp. coloniztion in broiler chickens. Poult. Sci., 80:156-160.

Teo, A. Y. and H. M. Tan, 2007. Evaluation of the performance and intestinal gut microflora of broilers fed on corn-soy diets supplemented with Bacillus subtilis PB6 (Clo STAT). J. Appl. Poult. Res., 16: 296-303.

Tollba, A. A. and R. M. Mahmoud 2009. How to control the broiler pathogenic intestinal flora under normal or heat stress conditions. Imedicinal plants, probiotics and sand as a litter. Egypt. Poult. Sci., 29: 565 - 587.

Torshizi, K. M. A.; A. R. Moghaddam; Sh. Rahimi and N. Mojgani, 2010. Assessing the effect of administering probiotics in water or as a feed supplement on broiler performance and immune response. Br. Poult. Sci., 51: 178-184.

Vicente, J. L.; A. Torres-Rodriguez; S. E. Higgins; C. Pixley; G. Tellez; A. M. Donoghue and B. M. Hargis, 2008. Effect of selected Lactobacillus spp-based probiotic on Salmonella enterica 
serovar enteritidis-infected broiler chicks. Avian Dis., 52: 143-146

Williams, C.J. and S. Zedeka, 2010. Comparative field evaluations of in ovo applied technology. Poult. Sci., 89:189-193.

Willis, W.L.; Z. Isikhuemheno and A. Ibrahims, 2007. Performance assessment of broiler chickens given mushroom extract alone or in combination with probiotics. Poult. Sci., 86: 1856-1860.

Yakhkeshi, S.; S. Rahimi and K. Gharib Naseri, 2011. The Effects of Comparison of Herbal Extracts, Antibiotic, Probiotic and Organic Acid on Serum Lipids, Immune Response, GIT Microbial Population, Intestinal Morphology and Performance of Broilers. Journal of Medicinal Plants.
Yamawaki, R. A.; E. L. Milbradt; M.P. Coppola; J. C. Rodrigues; R.L. Andreatti-Filho; C.R. Padovani and A.S. Okamoto, 2013. Effect of immersion and inoculation in ovo of Lactobacillus spp. in embryonated chicken eggs in the prevention of Salmonella enterides often hacth. Poult. Sci., 92: 1560 -1563.

Yusrizal, A. A. and T. C. chen, 2003. Effect of adding chicory fructans in feed on broiler growth performance, serum cholesterol and intestinal length. Int. J. Poult. Sci., 2: $214-219$.

Zhai, W.; D.E, Rowe and E.D. Peebles, 2011. Effects of commercial in ovo injection of carbohydrates on broiler embryogenesis. Poult. Sci., 90: 12951301.

استخدام بكتريا الكتو باسلس كحقن داخلي للبيضة أو التجريع الفموي لتحسين أداء كتاكيت بداري التسمين

امال محمد حسن" "إبراهيم الورداني" ، محمد إبراهيم شراب "

ا ققسم فسيولوجيا الحيوان و الدواجن- مركز بحوث الصحراء- القاهزة- مصر، ب قسم انتاج الدواجن، كلبة الزراعة، جامعة عين شعس، القاهرة مصر فيرل

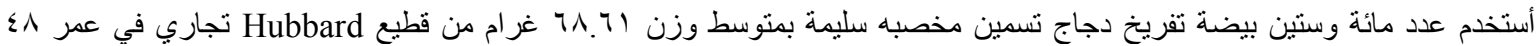

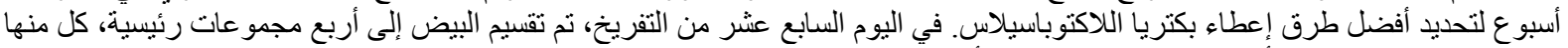

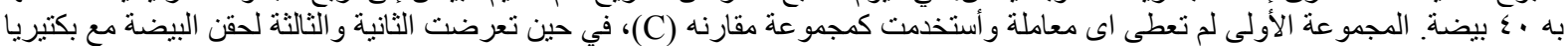

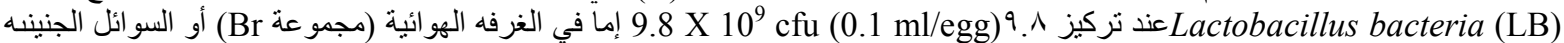

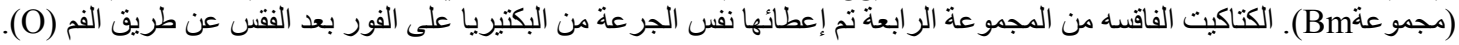

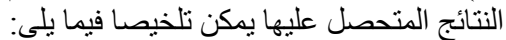

- إعطاء البكتريا عن طريق الفم أو بالحقن في البيضة له تأثير إيجابي على استهلاك العلف و الوزن الحي للكتكوت في الأسبوع الخامس من

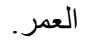

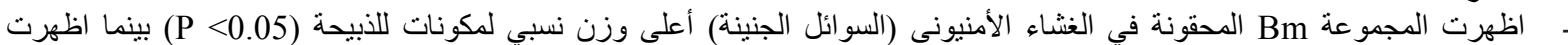

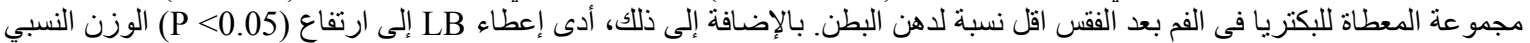
للكبد.

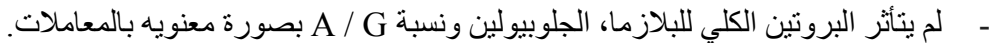

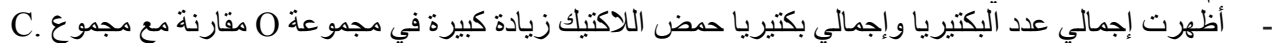

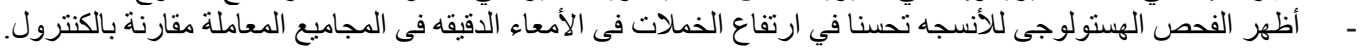

